\title{
Unveiling the Fecal Microbiota in Two Captive Mexican Wolf (Canis lupus baileyi) Populations Receiving Different Type of Diets
}

\author{
Sergio I. Barraza-Guerrero ${ }^{1}$, César A. Meza-Herrera ${ }^{2}\left(\mathbb{D}\right.$, Cristina García-De la Peña ${ }^{1, *(D)}$, \\ Verónica Ávila-Rodríguez ${ }^{1}$ (D) Felipe Vaca-Paniagua ${ }^{3,4,5}$ D , Clara E. Díaz-Velásquez ${ }^{3}$, Irene Pacheco-Torres ${ }^{6}$ (D), \\ Mónica A. Valdez-Solana ${ }^{7}{ }^{\mathbb{D}}$, Quetzaly K. Siller-Rodríguez ${ }^{1}$, Luis M. Valenzuela-Núñez ${ }^{1}$ \\ and Juan C. Herrera-Salazar ${ }^{1}$
}

1 Facultad de Ciencias Biológicas, Universidad Juárez del Estado de Durango, Gómez Palacio 35010, Mexico; sergiokun.barraza@gmail.com (S.I.B.-G.); vavilar@gmail.com (V.Á.-R.); qksr@hotmail.com (Q.K.S.-R.); luisvn70@hotmail.com (L.M.V.-N.); hsjc20@ujed.mx (J.C.H.-S.)

2 Unidad Regional Universitaria de Zonas Áridas, Universidad Autónoma Chapingo, Bermejillo 35230, Mexico; cmeza2020@hotmail.com

3 Laboratorio Nacional en Salud: Diagnóstico Molecular y Efecto Ambiental en Enfermedades

check for

updates

Citation: Barraza-Guerrero, S.I.; Meza-Herrera, C.A.; García-De la Peña, C.; Ávila-Rodríguez, V.; Vaca-Paniagua, F.; Díaz-Velásquez, C.E.; Pacheco-Torres, I.;

Valdez-Solana, M.A.;

Siller-Rodríguez, Q.K.;

Valenzuela-Núñez, L.M.; et al.

Unveiling the Fecal Microbiota in

Two Captive Mexican Wolf (Canis lupus baileyi) Populations Receiving Different Type of Diets. Biology 2021, 10, 637. https://doi.org/10.3390/ biology10070637

Academic Editor: Ger Rijkers

Received: 18 May 2021

Accepted: 5 July 2021

Published: 9 July 2021

Publisher's Note: MDPI stays neutral with regard to jurisdictional claims in published maps and institutional affiliations.

Copyright: (c) 2021 by the authors. Licensee MDPI, Basel, Switzerland. This article is an open access article distributed under the terms and conditions of the Creative Commons Attribution (CC BY) license (https:// creativecommons.org/licenses/by/ $4.0 /)$. Crónico-Degenerativas, Facultad de Estudios Superiores Iztacala, Universidad Nacional Autónoma de México, Tlalnepantla 54090, Mexico; felipe.vaca@gmail.com (F.V.-P.); cdiazvelasquez@aol.com (C.E.D.-V.)

4 Instituto Nacional de Cancerología, Ciudad de México 14080, Mexico

5 Unidad de Biomedicina, Facultad de Estudios Superiores Iztacala, Universidad Nacional Autónoma de México, Tlalnepantla 54090, Mexico

6 Programa de Posgrado en Recursos Genéticos y Productividad-Ganadería, Colegio de Postgraduados, Campus Montecillo, Km. 36.5 Carretera México-Texcoco, Montecillo 56230, Mexico; irenepacheco.t@gmail.com

7 Facultad de Ciencias Químicas, Universidad Juárez del Estado de Durango, Gómez Palacio 35010, Mexico; valdezandyval@gmail.com

* Correspondence: cristina.garcia@ujed.mx

Simple Summary: The Mexican wolf (Canis lupus baileyi) is an endangered canine. Both Mexico and the United States are currently collaborating to reproduce and reintroduce individuals to their original habitats. However, keeping these wolves in captivity represents a great commitment to meet their basic needs. Diet is a determining factor that is closely related to health and reproductive fitness. The type of diet that is fed to canines in captivity must provide the required nutrients for their development and welfare. The study of the fecal microbiota is a non-invasive way to establish the abundance and diversity of bacterial communities to determine if they are in a healthy condition. We analyzed data from two captive populations of Mexican wolves (i.e., northern and central Mexico) receiving different type of diets (Michilia population: mainly kibble vs. Ocotal population: mainly raw meat). The operational taxonomic units (OTUs) in Michilia resulted in 204 genera and 316 species, while in Ocotal there were 232 genera and 379 species. In the Michilia, dominance of bacteria that degrade carbohydrates was observed (related to kibble diet). In contrast, the Ocotal microbiota was dominated by protein-degrading bacteria (related to raw meat diet). The main outcomes generated in this study should help to enhance the welfare of the captive Mexican wolves to increase its numbers.

Abstract: The Mexican wolf (Canis lupus baileyi) was once distributed in southern United States and northern Mexico. It is an endangered subspecies detached from the gray wolf, and likely exemplifies one of the original migration waves of $C$. lupus into the new world. This is a canine whose individuals survive in specialized facilities, zoos, and museums as part of captive-breeding programs. In order to contribute to the improvement of the management of this species and favor its long-term conservation in Mexico, we aimed to evaluate the diversity and abundance of the fecal bacterial microbiota in two populations exposed to different types of diet: (1) Michilia $\left(23^{\circ} \mathrm{N}, 104^{\circ} \mathrm{W}\right)$; kibble daily and raw meat sporadically, and (2) Ocotal $\left(19^{\circ} \mathrm{N}, 99^{\circ} \mathrm{W}\right)$; raw meat daily and live animals periodically. Next generation sequencing (V3-V4 16S rRNA gene) by Illumina was implemented. The operational taxonomic units (OTUs) in Michilia resulted in 9 phyla, 19 classes, 34 orders, 61 families, 204 genera, 
and 316 species, while in Ocotal there were 12 phyla, 24 classes, 37 orders, 69 families, 232 genera, and 379 species. Higher estimated Chao1 richness, Shannon diversity, and core microbiota were observed in Ocotal. Differences $(p<0.05)$ between populations occurred according to the Bray-Curtis beta diversity index. In the Michilia, dominance of bacteria that degrade carbohydrates (Firmicutes, Lachnospiraceae, Blautia, Clostrodium, Eisenbergiella, Romboutsia, and Ruminococcus) was observed; they are abundant in kibble diets. In contrast, the Ocotal microbiota was dominated by proteindegrading bacteria (Fusobacteria, Fusobacteriaceae, and Fusobacteria), indicating a possible positive relation with a raw meat diet. The information generated in this study is fundamental to support the implementation of better management plans in the two populations considered here, as well as in different facilities of southern United States and Mexico, where this subspecies is kept in captivity for conservation purposes.

Keywords: microbiota; wolf; Michilia; Ocotal; diet; conservation

\section{Introduction}

The intestinal bacterial microbiota plays an important role in health and welfare of vertebrates. These bacteria, directly and indirectly, affect the physiology, immune system, and nutrition of the host through different mechanisms of biological coexistence such as mutualism, commensalism, and pathogenicity [1-3]. Some benefits provided by the intestinal microbiota are the following: it is a first defense barrier against pathogenic bacteria, promotes intestinal development, enhances fermentative processes to make substrates more easily digested, and produces vitamins for the host [4,5]. To recover threatened species, one of the most used strategies is bringing animals into captivity and intensively managing its populations [6]. However, captive management of wild populations implies to have not only a great knowledge of the biology and ecology of the species, but increased economic resources to try to recreate their free-life original inhabit conditions. In this respect, providing an adequate diet to a large canine species is one of the most challenging aspects for conservation organizations, as most of the time it is far from the nutritional composition they obtain in their natural environment [7]. In several canine species (red wolf, gray wolf, and dogs), diet changes have shown microbiological diversity and abundance alterations due to the different type of available substrates to digest [8-11]. As the imbalance of the intestinal bacterial communities may, in some cases, be associated with severe negative health consequences for the host [12], conservation efforts for threatened species kept in captivity have included the analysis of the host's fecal microbiota to monitor their health and promote their survival $[6,7,12]$.

The Mexican wolf (Canis lupus baileyi) is considered a subspecies separated from the gray wolf, and likely represents one of the earliest waves of migration of $C$. lupus into the new world [13]. It is an endemic species of Mexico [14], divergent form all other North American wolves' populations, suggesting that its presence in the Americas arises from a different colonization history regarding the remaining North American gray wolves [15]. Due to massive hunting by cattlemen in northern Mexico and southern USA, carried out at the beginning of the 20th century, this canine is currently considered extinct in free life $[16,17]$. A binational recovery program has been developed to reestablish Mexican wolves in Mexico and the USA [18]; this species had a great ecological importance because as a predator, it shaped the structure of biological communities, preserving diverse populations of plants and animals [19]. Currently, it is an emblematic species used as insignia for the conservation of biodiversity in Mexico [16]. Today, there are several specialized facilities, zoos, and museums that participate in the raising of Mexican wolves as part of the binational recovery program. In Mexico, there is a captivity facility located in the La Michilia Biosphere Reserve in the state of Durango, and another in the Ocotal State Park in the State of Mexico. The diet provided to the wolves in each of these facilities is different: (Michilia, Durango: kibble daily and raw meat sporadically, vs. Ocotal, 
State of Mexico: raw meat daily and live animals periodically). As the type of diet is an important factor in the fecal microbiota of canines, we quantified the diversity and abundance of the fecal bacterial microbiota (16S rRNA gene amplicon sequencing) of these two Mexican wolves' populations. We hypothesized a significant difference in the fecal bacterial microbiota between Michilia and Ocotal. The information generated in this study should contribute to improve the management policies and practices of captivity programs to preserve the Mexican wolf, benefiting its welfare and fitness, while favoring its long-term conservation.

\section{Materials and Methods}

\subsection{General}

All the methods and activities of this study were in strict accordance with accepted guidelines for ethical use, care, and welfare of animals in research at the international level [20]. The federal approval reference number is SEMARNAT SGPA/DGVS/05117/17.

\subsection{Location, Experimental Sites, Environmental Conditions and Animal Diets}

Michilia population. There is a biological station within the La Michilia Biosphere Reserve $\left(23^{\circ} 15^{\prime}\right.$ and $23^{\circ} 35^{\prime} \mathrm{N}, 104^{\circ}$ and $\left.104^{\circ} 20^{\prime} \mathrm{W}\right)$, located in the municipality of Suchil, southeast Durango, Mexico. The average altitude is $2480 \mathrm{~m}$ above sea level (m.a.s.l.) and the precipitation fluctuates between 600 and $860 \mathrm{~mm}$. There are two thermal zones, a temperate area located in the northern part, and on the slopes of hills (2700 m.a.s.l.) with an average annual temperature between 12 and $18{ }^{\circ} \mathrm{C}$. The other is a semi-cold area at altitudes greater than $2700 \mathrm{~m}$ with an average annual temperature below $12{ }^{\circ} \mathrm{C}$ [21]. The vegetation profiles fluctuate along with the altitude. The dominant vegetation is composed of pine-oak forest (Pinus spp. and Quercus spp.) and other tree species such as Pseudotsuga spp., Cupressus spp., and Juniperus spp. to a lesser extent [21]. This biological station involves three enclosures $\left(\approx 2000 \mathrm{~m}^{2}\right.$ each), where Mexican wolves are held. The diet offered for wolves in this location consists of commercial dry dog food (kibble; $16 \%$ protein, $7 \%$ fat, $12 \%$ water, $8 \%$ ash, $57 \%$ carbohydrates) on a daily basis, and fresh meat every 10-15 days. These wolves are totally isolated from the closest community, and have no contact with human beings, with the exception of the keeper who feeds them.

Ocotal population. The Ocotal State Park $\left(19^{\circ} 48\right.$ and $19^{\circ} 47^{\prime} \mathrm{N}, 99^{\circ} 45^{\prime}$ and $\left.99^{\circ} 45^{\prime} \mathrm{W}\right)$ is located in the municipality of Timilpan, State of Mexico, Mexico, within the Transversal Volcanic system. The area is located at an altitude of 2750 m.a.s.l., and occupies an area of 122.14 ha. In this region the climate is temperate, sub-humid, with precipitation greater than $550 \mathrm{~mm}$ [22]. In this park, the pine-ocote (Pinus oocarpa) predominates and there are also areas of oaks and grasslands [22]. In this location, the wolves are kept in a pack within an area close to $3500 \mathrm{~m}^{2}$; the wolves receive a diet consisted of fresh meat, and once a week of live rabbits or guinea pigs. These wolves are in a special area restricted to the public, where they only have contact with several keepers and veterinarians who care for them.

\subsection{Sampling According to Gender, Age, and Type of Animal Grouping}

In both geographical sites, animals were monitored at a distance of $10 \mathrm{~m}$ during the morning ( 800 to $1000 \mathrm{~h}$ ), awaiting the fecal evacuation. Stool samples were taken no more than $30 \mathrm{~min}$ after deposition. Stools that showed firm consistency were "opened" to sample the interior; for the watery feces, a sample was taken from the surface to avoid soil contamination. For each stool, approximately $0.3 \mathrm{~g}$ was collected in a BashingBead ${ }^{\mathrm{TM}}$ Zymo Research ${ }^{\mathrm{TM}}$ tube, adding $750 \mu \mathrm{L}$ of lysing solution Zymo Research ${ }^{\mathrm{TM}}$ stabilizer. Each tube was processed on a cell disruptor (TerraLyzer ${ }^{\mathrm{TM}}$ Zymo Research Corp., Irvine, CA, USA) for $30 \mathrm{~s}$ and transported to the lab in an ice box in the next four hours. The collected stool samples information regarding sex, age, and type of grouping are shown in Table 1. 
Table 1. Fecal samples collected according to location, sex, age, and type of grouping from two populations of Mexican wolves (Canis lupus baileyi) in Michilia $\left(\mathrm{M}, 23^{\circ} \mathrm{N}\right)$ and Ocotal $\left(\mathrm{O}, 19^{\circ} \mathrm{N}\right)$, Mexico.

\begin{tabular}{cccc}
\hline Location & Sex & Age (Years) & Grouping \\
\hline M1 & Female & 3 & Cohabitating with M2 \\
M2 & Female & 3 & Cohabitating with M1 \\
M3 & Male & 12 & Alone \\
M4 & Male & 2 & Cohabitating with M5 and M6 \\
M5 & Male & 2 & Cohabitating with M4 AND M6 \\
M6 & Male & 2 & Cohabitating with M4 AND M5 \\
O1 & Male & 3 & Pack \\
O2 & Male & 3 & Pack \\
O3 & Male & 1 & Pack \\
O4 & Female & 5 & Pack \\
O5 & Female & 5 & Pack \\
O6 & Female & 1 & Pack \\
O7 & Female & 1 & \\
\hline
\end{tabular}

\subsection{DNA Extraction and Visualization}

The QIAGEN DNeasy Blood and Tissue kit was used to extract the fecal DNA using a UV laminar flow hood with all sterility protocols. The DNA extraction products were run on $1.2 \%$ agarose gels at $80 \mathrm{~V}$ for $45 \mathrm{~min}$ in a Bio-Rad electrophoresis chamber to visualize the presence of DNA. Visualization was carried out on a GelMax ${ }^{\mathrm{TM}}$ photodocumenter $\left(\mathrm{UVP}^{\circledR}\right.$, Upland, CA, USA). The concentration and quality of DNA obtained from the samples was measured on a Qubit ${ }^{\circledR}$ 3.0. (Invitrogen, Carlsbad, CA, USA).

\section{5. $16 S$ rRNA Gene Amplicon Sequencing}

Amplification of the V3-V4 region of the $16 \mathrm{~S}$ rRNA gene was made using the following primers [23]: S-D-Bact-0341-b-S-17 5'-CCTACGGGNGGCWGCAG-3' and S-D-Bact-0785a-A-21 5'-GACTACHVGGGTATCTAATCC-3'. Subsequently, the Illumina PCR protocol, Illumina [24] was implemented using $12.5 \mu \mathrm{L}$ of MyTaq ${ }^{\mathrm{TM}}$ Ready Mix 1X (Bioline ${ }^{\circledR}$, London, UK), $1 \mu \mathrm{L}$ of each primer $(10 \mathrm{nM}), 5 \mu \mathrm{L}$ of DNA ( $25 \mathrm{ng}$ total) and $5.5 \mu \mathrm{L}$ of ultrapure $\mathrm{H}_{2} \mathrm{O}$; the following cycle was used: $95{ }^{\circ} \mathrm{C}$ for $3 \mathrm{~min} ; 25$ cycles of $95{ }^{\circ} \mathrm{C}$ for $30 \mathrm{~s}, 55^{\circ} \mathrm{C}$ for $30 \mathrm{~s}, 72{ }^{\circ} \mathrm{C}$ for $30 \mathrm{~s}$; and $72{ }^{\circ} \mathrm{C}$ for $5 \mathrm{~min}$ in a Labnet Multigene ${ }^{\mathrm{TM}}$ Gradient PCR (Labnet International, Inc. Global, Edison, NJ, USA) thermal cycler. Amplicons were purified with $0.8 \%$ Agentcourt ${ }^{\circledR}$ AMPure ${ }^{\circledR}$ XP beads (Beckman Coulter Inc., Brea, CA, USA). Then, the amplicons were labeled using Nextera XT Index Kit ${ }^{\mathrm{TM}}$ (Illumina, Inc., San Diego, CA, USA) for the creation of the libraries, following the Illumina protocol [25], using $25 \mu \mathrm{L}$ of MyTaq $^{\mathrm{TM}}$ Ready Mix 1X $\left(\right.$ Bioline $\left.^{\circledR}\right), 5 \mu \mathrm{L}$ of each primer (N7xx and S5xx), $5 \mathrm{uL}$ of DNA, and $10 \mu \mathrm{L}$ of ultrapure $\mathrm{H}_{2} \mathrm{O}$; the following cycle was used: $95^{\circ} \mathrm{C}$ for $3 \mathrm{~min} ; 10$ cycles of $95^{\circ} \mathrm{C}$ for $30 \mathrm{~s}, 55^{\circ} \mathrm{C}$ for $30 \mathrm{~s}, 72{ }^{\circ} \mathrm{C}$ for $30 \mathrm{~s}$; and $72{ }^{\circ} \mathrm{C}$ for $5 \mathrm{~min}$. Finally, quantification, normalization (equimolarity), library pooling, and next-generation massive sequencing (MiSeq, Illumina, San Diego, CA, USA) of $2 \times 250$ paired end reads) were performed following the Illumina $16 \mathrm{~S}$ protocol [24].

\subsection{Bio-Informatic Analyses}

Sequence analysis was performed using Quantitative Insights into Microbial Ecology (QIIME) [26]. The assembly was made using PEAR [27] with Q30. Chimeras were removed with USEARCH [28]. Operational taxonomic units (OTUs) were selected using UCLUST [28] at $97 \%$ similarity; taxonomy was assigned using EzBioCloud database [29]. Random rarefaction was carried out at a depth of 13,050 sequences. From here, the Chao1 estimated richness index and the Shannon alpha diversity index were calculated. Non-parametric $t$-tests (false discovery rate correction) were applied to test differences $(p<0.05)$ between populations for each index. The Bray-Curtis beta diversity [30] was calculated; PERMANOVA was applied to test significant differences $(p<0.05)$ of the fecal microbiota between populations, and it was visualized using principal coordinate analysis ( $\mathrm{PCoA}$ ) in Emperor [31]. The relative 
bacterial abundance was obtained at all taxonomic levels. The most abundant phyla and families were represented in stacked bar graphs using $R$, and the genera were visualized in a heatmap using Morpheus (https:/ / software.broadinstitute.org/GENE-E/; accessed 15 January 2021). To establish the bacterial taxa at phylum, family and genus levels that contributed the most to the differentiation of the fecal microbiota between both populations, a percentage similarity analysis SIMPER [32] was developed using the Bray-Curtis matrix in PAST 4.0. For those taxa whose contribution was greater than $0.2 \%$, a Mann-Whitney $\mathrm{U}$ test $(p<0.05)$ was applied to test for significant differences between populations. We also determined the core microbiota (those taxa that are found in all individuals) for each population. Finally, a LEfSe (linear discriminant analysis effect size) analysis was performed to statistically and biologically determine the key biomarkers which contribute the most to the differences between populations. The clades selected were those less than 0.05 in the alpha value of the Kruskal-Wallis factorial test $>4.0$ in the logarithmic LDA score [33]. This analysis was made on the website http://huttenhower.sph.harvard.edu/lefse/ (accessed 25 January 2021).

\section{Results}

The mean of assembled sequences for the Michilia wolves was 38,402, and for Ocotal was 56,663. The mean of quality bacterial sequences in the Michilia samples was 26,467, and 37,043 for the Ocotal samples. The mean OTUs were 1475 and 3449, respectively (Table 2). The OTUs in the Michilia population resulted in 9 phyla, 19 classes, 34 orders, 61 families, 204 genera, and 316 species, while in Ocotal there were observed 12 phyla, 24 classes, 37 orders, 69 families, 232 genera, and 379 species.

Table 2. Fecal samples sequences obtained from two populations of Mexican wolves (Canis lupus baileyi) in Michilia $\left(\mathrm{M}, 23^{\circ} \mathrm{N}\right)$ and $\operatorname{Ocotal}\left(\mathrm{O}, 19^{\circ} \mathrm{N}\right)$, Mexico.

\begin{tabular}{ccccc}
\hline Location & Total Reads & Assembled Reads & QB $^{\mathbf{1}}$ & OTUs $^{2}$ \\
\hline M1 & 142,533 & 42,013 & 35,441 & 735 \\
M2 & 190,819 & 20,205 & 13,051 & 1074 \\
M3 & 168,432 & 49,194 & 31,220 & 2537 \\
M4 & 150,884 & 49,018 & 33,674 & 1836 \\
M5 & 132,288 & 41,866 & 25,773 & 1631 \\
M6 & 181,892 & 28,113 & 19,643 & 1038 \\
Mean & 161,141 & 38,402 & 26,467 & 1475 \\
O1 & 119,488 & 46,215 & 28,913 & 3085 \\
O2 & 141,153 & 61,695 & 43,526 & 3506 \\
O3 & 140,534 & 64,251 & 44,318 & 3512 \\
O4 & 151,679 & 76,461 & 54,132 & 3891 \\
O5 & 119,588 & 51,454 & 34,252 & 3430 \\
O6 & 128,670 & 57,787 & 35,222 & 3554 \\
O7 & 89,352 & 38,777 & 18,936 & 3165 \\
Mean & 127,209 & 56,663 & 37,043 & 3449 \\
\hline
\end{tabular}

${ }^{1} \mathrm{QB}=$ Quality bacterial sequences; ${ }^{2}$ OTUs = operational taxonomic units.

The estimated Chao1 richness index differed $(p<0.001)$ between populations $(t=5.829$, $p<0.001$; Figure 1A). The mean Chao1 index for the Michilia samples was 2007.07 \pm 1067.46 (SD), compared to $4705.56 \pm 565.26$ (SD) in Ocotal. Likewise, a significant difference was observed in the Shannon alpha diversity index $(t=6.538, p<0.001$; Figure $1 \mathrm{~B})$. While the mean Shannon index for the Michilia samples was $4.89 \pm 0.41$ (SD), a greater index occurred in the Ocotal (5.95 $\pm 0.12(\mathrm{SD}))$. Differences also occurred between populations regarding the Bray-Curtis beta diversity matrix (PERMANOVA: pseudo- $\mathrm{F}=7.63 ; p=0.002$; Figure 2). These results indicated that the group segregation is considerable, confirming a significant difference in the bacterial community structure between populations. 


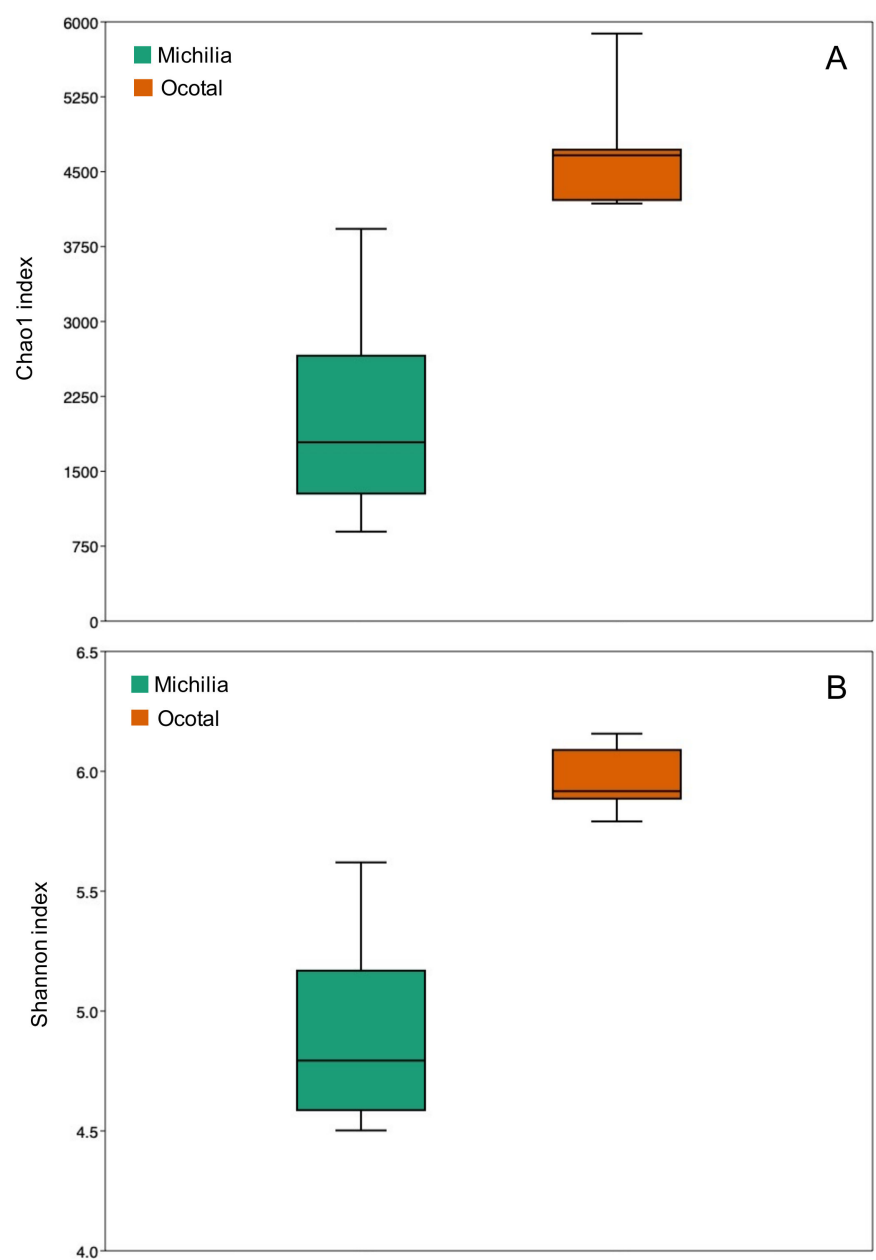

Figure 1. Boxplots of (A) Chao1 richness index and (B) Shannon alpha diversity index for the bacterial microbiota from two populations of Mexican wolves (Canis lupus baileyi) in Michilia $\left(\mathrm{M}, 23^{\circ} \mathrm{N}\right)$ and Ocotal $\left(\mathrm{O}, 19^{\circ} \mathrm{N}\right)$, Mexico.

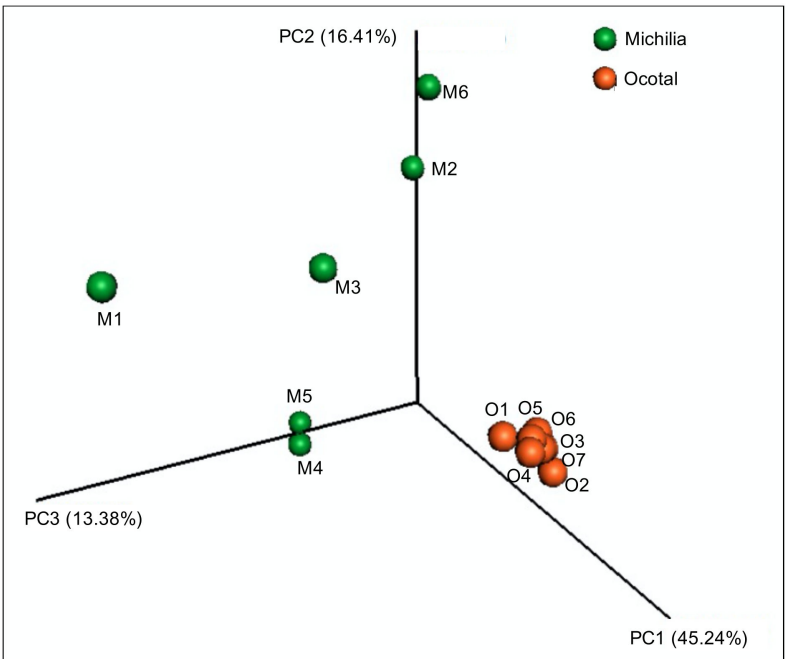

Figure 2. Principal Coordinate Analysis (PCoA) plot based on Bray-Curtis index of the fecal bacterial microbiota from two populations of Mexican wolves (Canis lupus baileyi) in Michilia $\left(\mathrm{M}, 23^{\circ} \mathrm{N}\right.$ ) and Ocotal $\left(\mathrm{O}, 19^{\circ} \mathrm{N}\right)$, Mexico.

The most abundant phyla were Firmicutes $(\bar{x}=58.9 \%)$ and Proteobacteria $(\bar{x}=20.2 \%)$ in the Michilia population, and Fusobacteria $(\bar{x}=74.4 \%)$ and Firmicutes $(\bar{x}=23.7 \%)$ in the 
Ocotal population (Figure 3). The SIMPER analysis showed a global dissimilarity between both groups of 66.03, with three phyla contributing with $91.07 \%$ of the difference (Fusobacteria, Firmicutes, and Proteobacteria), Fusobacteria being more abundant in Ocotal, while Firmicutes and Proteobacteria in Michilia (Table 3). At the family level, the most abundant taxa in Michilia were Lachnospiraceae $(\bar{x}=34.9 \%)$, Succinivibrionaceae $(\bar{x}=15.9 \%)$, and Peptostreptococcaceae $(\bar{x}=12.6 \%)$. Regarding the Ocotal, the most abundant were Fusobacteriaceae $(\bar{x}=74.4 \%)$, Lachnospiraceae $(\bar{x}=8.1 \%)$, and Ruminococcaceae $(\bar{x}=7.5 \%)$ (Figure 4).

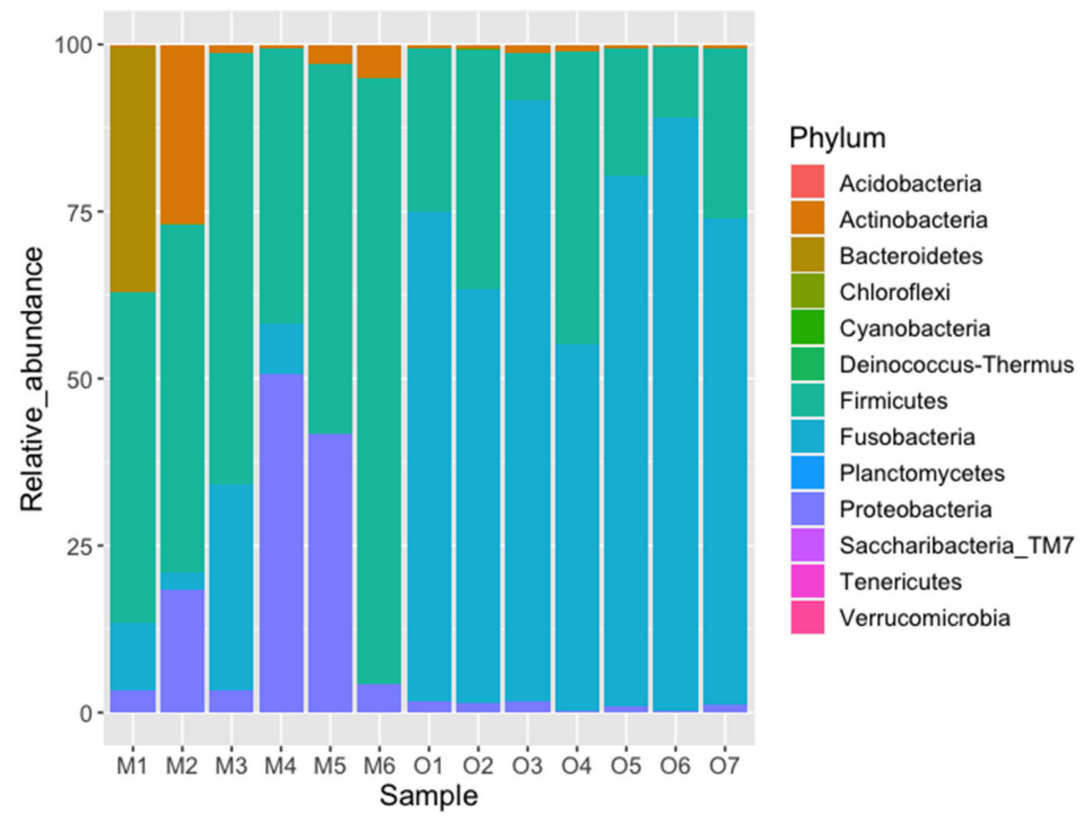

Figure 3. Relative abundance (\%) of fecal bacterial taxa (phylum level) from two populations of Mexican wolves (Canis lupus baileyi) in Michilia $\left(\mathrm{M}, 23^{\circ} \mathrm{N}\right)$ and Ocotal $\left(\mathrm{O}, 19^{\circ} \mathrm{N}\right)$, Mexico.

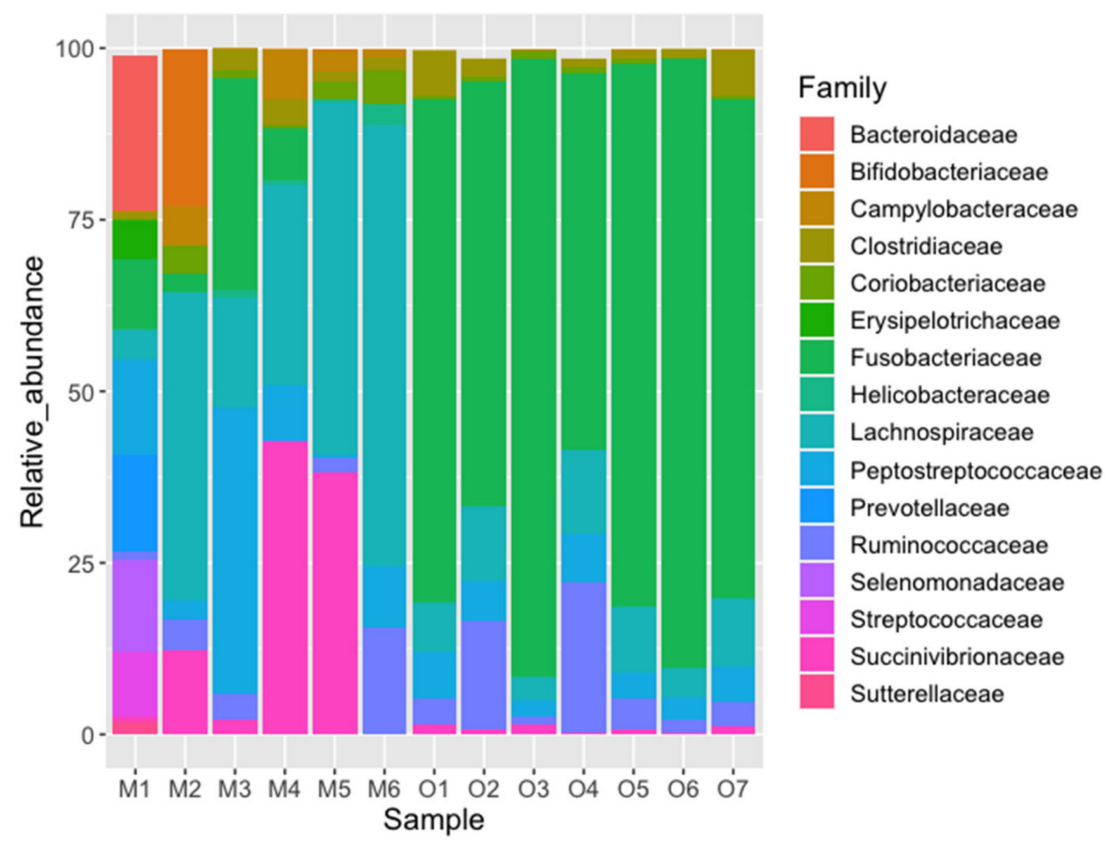

Figure 4. Relative abundance (\%) of the fecal bacterial taxa (family level) from two populations of Mexican wolves (Canis lupus baileyi) in Michilia $\left(\mathrm{M}, 23^{\circ} \mathrm{N}\right)$ and Ocotal $\left(\mathrm{O}, 19^{\circ} \mathrm{N}\right)$, Mexico; only the first 16 more abundant families are shown. 
Table 3. Percentage similarity analysis (SIMPER) considering the average of dissimilarity (AVD) of fecal bacteria at phyla, family, and genus levels from two populations of Mexican wolves (Canis lupus baileyi) in Michilia (M, 23 $\left.{ }^{\circ} \mathrm{N}\right)$ and Ocotal (O, $\left.19^{\circ} \mathrm{N}\right)$, Mexico.

\begin{tabular}{|c|c|c|c|c|c|c|c|}
\hline Taxon & AVD & Contribution $\%$ & Cumulative $\%$ & Mean $\mathbf{M}$ & Mean O & $\mathbf{U}$ & $p$-Value \\
\hline \multicolumn{8}{|l|}{ Phylum } \\
\hline Fusobacteria & 32.93 & 49.87 & 49.87 & 0.085 & 0.744 & 0 & 0.001 \\
\hline Firmicutes & 17.63 & 26.69 & 76.56 & 0.589 & 0.238 & 1 & 0.001 \\
\hline Proteobacteria & 9.58 & 14.51 & 91.07 & 0.202 & 0.011 & 0 & 0.001 \\
\hline Bacteroidetes & 3.07 & 4.64 & 95.72 & 0.061 & 0.000 & 14 & 0.353 \\
\hline Actinobacteria & 2.81 & 4.26 & 99.98 & 0.062 & 0.007 & 13 & 0.283 \\
\hline \multicolumn{8}{|l|}{ Family } \\
\hline Fusobacteriaceae & 32.93 & 44.01 & 44.01 & 0.085 & 0.744 & 0 & 0.001 \\
\hline Lachnospiraceae & 14.09 & 18.83 & 62.84 & 0.350 & 0.082 & 6 & 0.038 \\
\hline Succinivibrionaceae & 7.75 & 10.36 & 73.20 & 0.160 & 0.009 & 12 & 0.224 \\
\hline Peptostreptococcaceae & 4.92 & 6.57 & 79.77 & 0.126 & 0.049 & 13 & 0.283 \\
\hline Ruminococcaceae & 3.30 & 4.41 & 84.18 & 0.046 & 0.075 & 15 & 0.432 \\
\hline Bifidobacteriaceae & 1.94 & 2.59 & 86.77 & 0.039 & 0.000 & - & - \\
\hline Bacteroidaceae & 1.89 & 2.52 & 89.29 & 0.038 & 0.000 & 14 & 0.350 \\
\hline Campylobacteraceae & 1.43 & 1.90 & 91.19 & 0.029 & 0.001 & 5 & 0.026 \\
\hline Prevotellaceae & 1.18 & 1.58 & 92.77 & 0.024 & 0.000 & - & - \\
\hline Clostridiaceae & 1.14 & 1.52 & 94.29 & 0.019 & 0.027 & 20 & 0.943 \\
\hline Selenomonadaceae & 1.13 & 1.51 & 95.80 & 0.023 & 0.000 & - & - \\
\hline Coriobacteriaceae & 0.89 & 1.19 & 96.99 & 0.023 & 0.007 & 13 & 0.283 \\
\hline Streptococcaceae & 0.77 & 1.03 & 98.02 & 0.015 & 0.000 & - & - \\
\hline Helicobacteraceae & 0.46 & 0.62 & 98.64 & 0.010 & 0.000 & 0 & 0.003 \\
\hline \multicolumn{8}{|l|}{ Genus } \\
\hline Fusobacterium & 33.14 & 41.80 & 41.80 & 0.081 & 0.744 & 0 & 0.001 \\
\hline Anaerobiospirillum & 7.75 & 9.78 & 51.58 & 0.160 & 0.008 & 12 & 0.224 \\
\hline Blautia & 6.71 & 8.47 & 60.05 & 0.157 & 0.045 & 15 & 0.432 \\
\hline Clostridium_g21 & 4.50 & 5.68 & 65.73 & 0.091 & 0.001 & 0 & 0.001 \\
\hline Other & 2.51 & 3.16 & 68.89 & 0.069 & 0.039 & 13 & 0.283 \\
\hline Sporobacter & 2.31 & 2.91 & 71.80 & 0.000 & 0.046 & 0 & 0.001 \\
\hline Romboutsia & 2.10 & 2.65 & 74.45 & 0.043 & 0.001 & 5 & 0.026 \\
\hline Other & 2.06 & 2.59 & 77.04 & 0.048 & 0.011 & 13 & 0.283 \\
\hline Bifidobacterium & 1.94 & 2.44 & 79.48 & 0.039 & 0.000 & - & - \\
\hline Bacteroides & 1.89 & 2.38 & 81.86 & 0.038 & 0.000 & 14 & 0.350 \\
\hline Campylobacter & 1.43 & 1.80 & 83.66 & 0.029 & 0.001 & 5 & 0.026 \\
\hline Faecalibacterium & 1.20 & 1.52 & 85.17 & 0.029 & 0.013 & 16 & 0.520 \\
\hline Alloprevotella & 1.18 & 1.49 & 86.66 & 0.024 & 0.000 & - & - \\
\hline Megamonas & 1.13 & 1.43 & 88.09 & 0.023 & 0.000 & - & - \\
\hline Clostridium & 1.08 & 1.37 & 89.45 & 0.016 & 0.027 & 20 & 0.943 \\
\hline Anaerotignum & 1.01 & 1.28 & 90.73 & 0.020 & 0.002 & 19 & 0.829 \\
\hline Collinsella & 0.90 & 1.14 & 91.87 & 0.022 & 0.005 & 6 & 0.038 \\
\hline Clostridium_g24 & 0.84 & 1.06 & 92.93 & 0.021 & 0.010 & 19 & 0.830 \\
\hline Streptococcus & 0.76 & 0.96 & 93.90 & 0.015 & 0.000 & - & - \\
\hline Fournierella & 0.62 & 0.78 & 94.68 & 0.013 & 0.000 & 6.5 & 0.045 \\
\hline Helicobacter & 0.46 & 0.58 & 95.26 & 0.010 & 0.000 & 0 & 0.001 \\
\hline Clostridioides & 0.45 & 0.56 & 95.83 & 0.012 & 0.008 & 20 & 0.943 \\
\hline Oscillibacter & 0.20 & 0.26 & 96.35 & 0.001 & 0.004 & 9 & 0.100 \\
\hline Turicibacter & 0.17 & 0.22 & 96.81 & 0.003 & 0.000 & - & - \\
\hline
\end{tabular}

The SIMPER analysis showed an overall dissimilarity of 74.83 between populations. Fusobacteriaceae were more abundant $(p<0.05)$ in Ocotal, while Lachnospiraceae, Campylobacteraceae, and Helicobacteraceae were more numerous in Michilia (Table 3). The most abundant bacterial genera in Michilia were Anaerobiospirillum $(\bar{x}=15.9 \%)$, Blautia $(\bar{x}=15.70 \%)$, and Fusobacterium $(\bar{x}=8.1 \%)$, while in the Ocotal were Fusobacterium $(\bar{x}=74.3 \%)$, Sporobacter $(\bar{x}=4.6 \%)$, and Blautia $(\bar{x}=4.5 \%)$ (Figure 5). The SIMPER analysis showed a global dissimilarity of 79.27 between populations, where the abundances of Fusobacterium and Sporobacter were higher $(p<0.05)$ in Ocotal, while Clostridium_g21, Romboutsia, Campylobacter, Collinsella, Fournierella, and Helicobacter were more abundant in Michilia (Table 3). The complete list of fecal bacterial microbiota (from phylum to species) for both Mexican wolf populations is shown in Table S1. The core microbiota analysis showed 11 bacterial genera for Michilia and 23 for Ocotal (Table 4). 


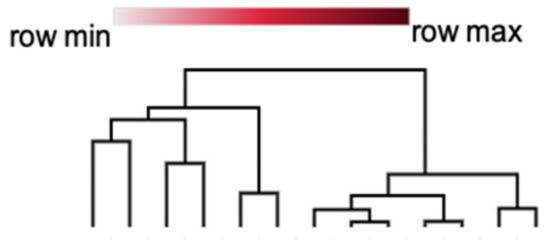

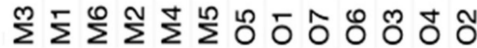

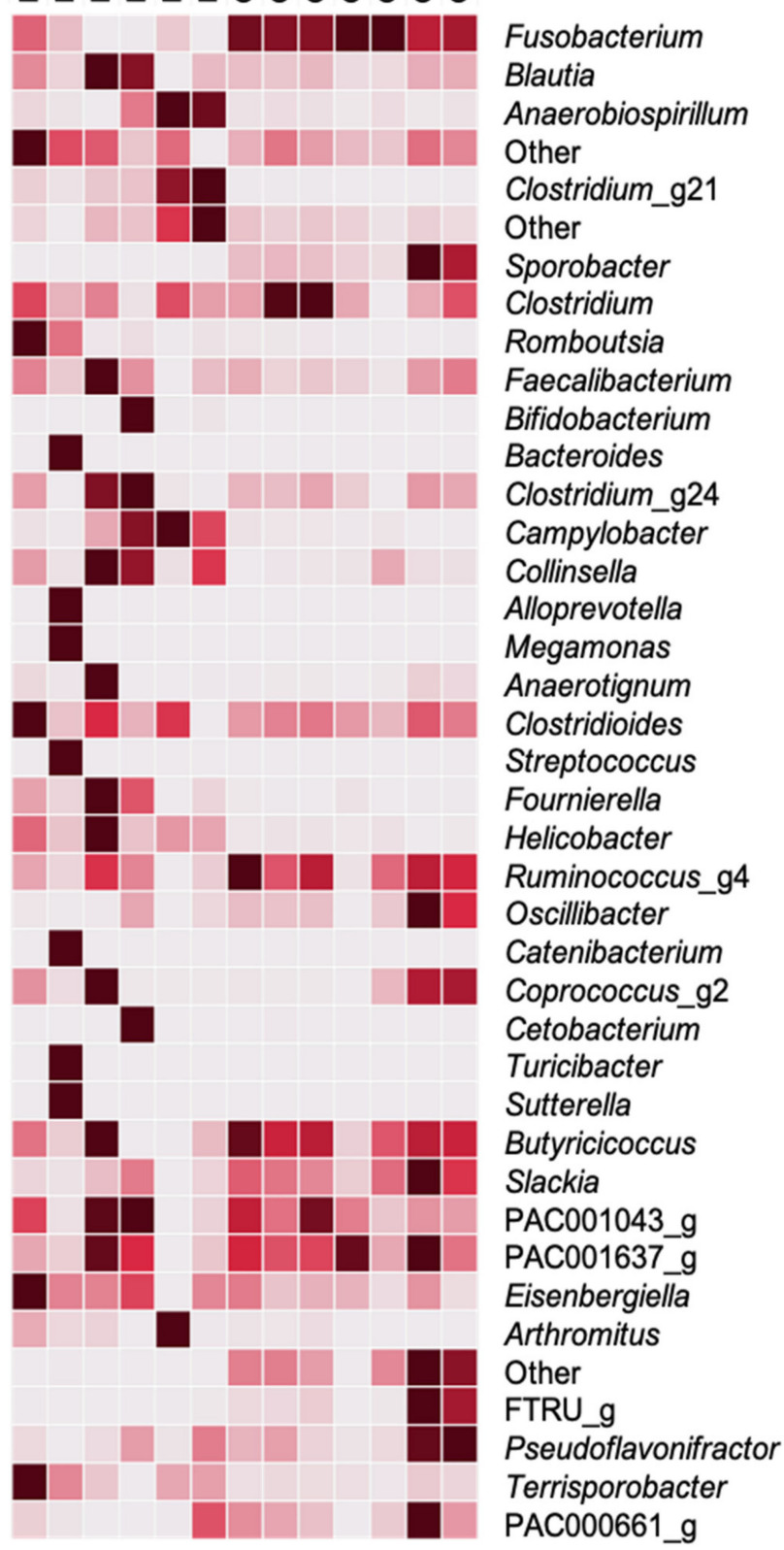

Figure 5. Heatmap of the fecal bacterial taxa (genera level) from two populations of Mexican wolves (Canis lupus baileyi) in Michilia $\left(\mathrm{M}, 23^{\circ} \mathrm{N}\right)$ and Ocotal $\left(\mathrm{O}, 19^{\circ} \mathrm{N}\right)$, Mexico; only the first 40 more abundant genera are shown.

LefSe analysis showed differences at taxa level between Michilia and Ocotal Mexican wolves. The bar graph from LefSe analysis (Figure 6A) displays LDA scores of microbial taxa with significant differences between populations. Firmicutes and Proteobacteria phyla, Clostridia class, Clostridiales order, Lachnospiraceae family, and Clostridium_g21 genus were enriched in the Mexican wolves of the Michilia population. For the Ocotal population, enrichment was observed in the Fusobacteria phylum, Fusobacteria_c class, Fusobacteriales 
order, Fusobacteriaceae family, and Fusobacterium and Clostridium_g34 genera. Principal biomarkers are shown in a cladogram (Figure 6B).

Table 4. Core fecal bacterial microbiota (taxa that were found in all individuals) from two populations of Mexican wolves (Canis lupus baileyi) in Michilia $\left(\mathrm{M}, 23^{\circ} \mathrm{N}\right)$ and $\operatorname{Ocotal}\left(\mathrm{O}, 19^{\circ} \mathrm{N}\right)$, Mexico.

\begin{tabular}{|c|c|c|}
\hline \multirow[b]{2}{*}{ Genera/Species } & \multicolumn{2}{|c|}{ Core Microbiota } \\
\hline & Michilia & Ocotal \\
\hline Agathobaculum & - & * \\
\hline Anaerobiospirillum & - & * \\
\hline Blautia & * & * \\
\hline Butyricicoccus & - & * \\
\hline Campylobacter & * & * \\
\hline Clostridium & * & * \\
\hline Clostridium_g21 & * & * \\
\hline Clostridium_g24 & * & * \\
\hline Collinsella & * & * \\
\hline Eisenbergiella & * & * \\
\hline Faecalibacterium & - & * \\
\hline Faecalimonas & - & * \\
\hline Fusobacterium & - & * \\
\hline Fusobacterium necrophorum & - & * \\
\hline GU302778_g & - & * \\
\hline Helicobacter & * & * \\
\hline PAC001043_g & * & * \\
\hline PAC001200_g & - & $*$ \\
\hline PAC001637_g & - & $*$ \\
\hline Romboutsia & * & - \\
\hline Roseburia & - & * \\
\hline Ruminococcus_g4 & * & * \\
\hline Slackia & - & * \\
\hline Sporobacter & - & * \\
\hline
\end{tabular}

$\left({ }^{*}\right)$ denotes presence, $(-)$ denotes absence.

A

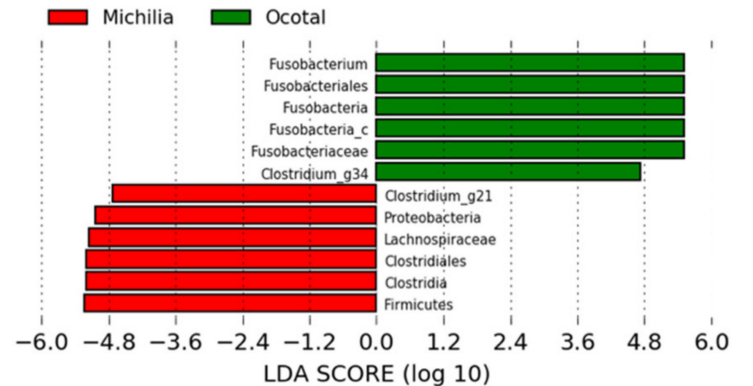

B

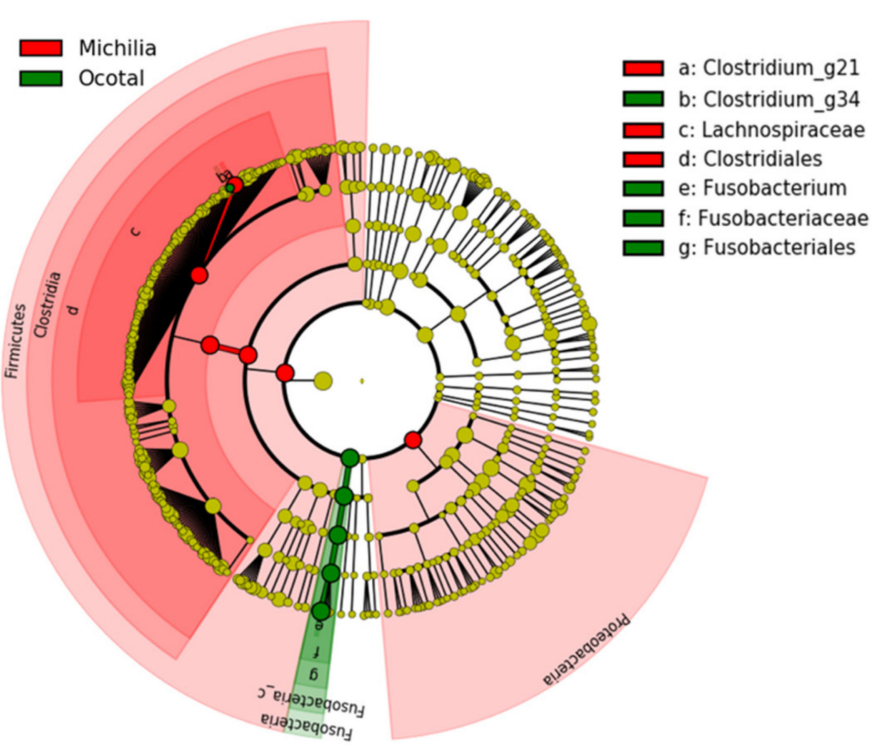

Figure 6. LEfSe analysis of fecal bacterial microbiota from two populations of Mexican wolves (Canis lupus baileyi) in Michilia and Ocotal, Mexico. (A) Bar graph shows LDA scores which indicate the taxonomic key for differentiation between populations. (B) The cladogram generated by LEfSe indicates the main biomarkers between populations. Each successive circle represents one phylogenetic level. Red-colored regions indicate taxa enriched in Michilia Mexican wolves, while green-colored regions indicate taxa enriched in Ocotal Mexican wolves. 


\section{Discussion}

It has been documented that abundance and diversity of the canine fecal microbiota is influenced by age, diet, health status, peer-social relationships, and anthropogenic-animal interactions, among other variables [9,34-36]. In the present study, the fecal bacterial microbiota of two Mexican wolf populations was evaluated. Although the geographical separation between populations is considerable, the type of habitat (temperate forest) in each locality was similar. Likewise, individuals from both populations have contact only with the personnel in charge of their care. However, Michilia and Ocotal differ in terms of grouping, age, and diet. While the Michilia wolves were separated either individually, or in pairs or trios (ages from 3 to 12 years old), Ocotal wolves lived together in a pack (average 3 yaers old). Regarding the diet, the wolves of Michilia were fed with kibble daily and raw meat sporadically, and in Ocotal the diet was based on raw meat daily and live animals periodically. Although it is probable that the type of interaction between individuals and the different ages may contribute to the difference in fecal microbiota observed in the present study, diet is considered a main factor closely related to the type of bacterial communities present in the intestine of vertebrates [10,12]; this variable will be discussed further.

Significant difference was observed in the fecal microbiota between populations, where the Ocotal wolves showed greater specific richness, higher within samples diversity of OTUs, and more than twice bacterial genera in its core microbiota compared to Michilia wolves. Previous studies have documented that wolves and dogs fed with raw meat show Bacteroidetes (46.4\%), Fusobacteria (30.5\%), Firmicutes (13.4\%), Proteobacteria (8.8\%) and Actinobacteria (0.5\%) as the most abundant fecal bacteria at phylum level [8-10]. These same phyla were recorded as part of the fecal microbiota in the two studied Mexican wolves' populations. However, in the Michilia wolves, an increased frequency of Firmicutes (58\%) occurred, followed by Proteobacteria (20\%); it must be highlighted that the diet offered to these animals was based on a low-quality kibble (low protein, $16 \%$, and high carbohydrates, $57 \%$ ), and eventually on raw meat. Therefore, the low-quality feed provided to these animals could explain the difference between the dominant phyla found and those expected if a high-quality meat-based or kibble diet had been provided. Diet studies on wolves and dogs have established that Firmicutes is abundant in canines eating diets based on low to medium-quality kibble or canned commercial food, due to its high carbohydrate content (30 to $60 \%$ starch), which favors proliferation of this phylum [11,12]. On the other hand, in the Ocotal wolves, the predominant phylum was Fusobacteria (i.e., 74\%). In this population, the daily diet was raw meat, as well as live rabbits and guinea pigs weekly to encourage their hunt drives. Diets based on raw meat and BARF (i.e., Bones and Raw Food) are rich in proteins, increasing the abundance of Fusobacteria [8,34]. At the family level, the SIMPER analysis registered a greater abundance of Lachnospiraceae (phylum Firmicutes) in Michilia wolves, while a predominance of Fusobacteriaceae family (phylum Fusobacteria) was observed in the Ocotal wolves. Likewise, the LEFSE analysis showed that these two families are important biomarkers of the fecal microbiota in the analyzed populations. At the genus level, some of the taxa reported in previous canine studies were Bacteroides, Blautia, Catenibacterium, Clostridium, Collinsella, Coprobacillus, Corynebacterium, Fusobacterium, Megamonas, Prevotella, and Turicibacter [10,37-39]. These genera coincide with those registered as part of the Mexican wolf's fecal microbiota in the present study. Nonetheless, the most abundant genera detected in Michilia wolves were Anaerobiospirillum and Blautia, accounting $15 \%$ of relative abundance. From these two genera, only Blautia was part of the core microbiota of this population, along with Campylobacter, Clostrodium, Collinsella, Eisenbergiella, Helicobacter, Romboutsia, and Ruminococcus. Interestingly, most of them belong to the phylum Firmicutes, indicating that, also at the genus level, the microbiota of these wolves has been conditioned to a diet rich in carbohydrates (57\%). Conversely, in the Ocotal wolves, a dominance of the genus Fusobacterium was registered $(74 \%)$, and the LefSe indicates that this taxon appears as a biomarker for this population. 
This genus has been profusely reported in canines fed raw meat [40] and has also been associated with healthy dogs living outdoors [41,42].

In general, wild canine species are adapted to a diet based on prey animals (high protein content) [43-45]. However, some conservation facilities have chosen to feed commercial dog products to captive wolves, due to their low cost and ease of handling compared to meat-based diets. In fact, commercial products can be an excellent option to preserve a good health status in these species, as long as these animals receive a high-quality product. On this respect, the Association of Zoos and Aquariums and the Animal Welfare Committee [7], recommend that commercial food for large canines (Canis lupus and its subspecies) should contain $20-28 \%$ protein, $5-10 \%$ fat, and $2-4 \%$ crude fiber. Specifically, for the Mexican wolf, the US Fish and Wildlife Service [46], recommends commercial food with $29 \%$ protein, $18 \%$ fat, $12 \%$ water, $9 \%$ ash, and 32\% carbohydrates (Mazuri Exotic Canine Diet (5MN2)). When a low-quality kibble (like the one provided in Michilia) is offered, an alteration in the functional diversity of the intestinal microbiota could occur, generating gastric discomfort, loose/watery stools, or even diarrhea $[8,47,48]$. When evaluating the relationship between the consistency of feces and different types of diets in red wolf (Canis rufus), Bragg et al. (2020) [8], reported that the feces tended to be loose or even watery when the diet is based on low-quality kibble, and certain bacterial genera such as Blautia and Romboutsia were associated with this abnormal fecal condition. In our study, four (M1, M2, M3, and M6) of six fecal samples collected from the Michilia wolves were loose or watery (3.5 to 4 according to the Whaltham faeces scoring system [49]), while the genera associated to this fecal condition (i.e., Blautia and Romboutsia) were relatively abundant in these individuals. Additionally, according to Wu et al. (2017) [9], the proportion of Proteobacteria and Actinobacteria in wolves consuming appropriate diets is $8.8 \%$ and $0.5 \%$, respectively. However, the Michilia wolves showed an average of $20 \%$ in Proteobacteria, while the M2-wolf showed 2.6\% of Actinobacteria, indicating an imbalance of abundance in these phyla. Another study evaluated dogs of different ages, sexes, and breeds, and reported that changes in diet (from raw meat or cooked to kibble) led to an increase in the abundance of Proteobacteria [40,50,51]. Nonetheless, significant increases in these two phyla have been reported in dogs suffering from inflammatory bowel disease (IBD) [52,53]. It is possible that this imbalance in the Michilia wolves' microbiota may have contributed to the observed watery stools, but the main concern is that this condition could lead to serious gastric disorders if the main problem (low-quality food) is not addressed. According to the facility staff, it is common to find loose feces from these wolves every day. Therefore, it is highly recommended that this facility considers changing to a higher quality food according to the nutritional guidelines provided by the US Fish and Wildlife Service [46]. All facilities that keep wild canines and other species of animals in captivity should follow management plans in which the health and welfare of all individuals is a priority.

\section{Conclusions}

The fecal bacterial microbiota of the Mexican wolf characterized in two populations, was affected by the different diets that the wolves have access to. In the Michilia wolves, with a diet based on high carbohydrate kibble and occasionally on raw meat, an increased frequency of Firmicutes and Proteobacteria occurred. On the contrary, in the Ocotal wolves, the most predominant phylum was Fusobacteria; these wolves were mainly feed with a high-protein diet, based on raw meat and live prey, increasing the abundance of Fusobacteria. It is recommended that the facilities where Mexican wolves are raised could maintain a constant evaluation of the diet provided to their animals, and improve it if necessary (e.g., high-quality kibble), to maintain the best possible digestive health in their individuals. While we still have a fragmentary knowledge regarding the main factors that shape the intestinal microbiota in the Mexican wolf, the main information generated in this study should help to enhance the welfare of these canines kept in captivity, while supporting diverse reproductive programs to increase its numbers. Being an endemic species of Mexico, not only the government authorities, but also the wildlife policy makers, civil organizations, 
and the scientific-academic community, have an enormous responsibility to reverse the damage that years ago placed this species on the brink of extinction. This astonishing while utmost endangered wolf species deserves our thoroughgoing commitment to do so, with the core aim to uphold a plentiful while ample recolonization of its former historical range; an undoubtedly pending assignment.

Supplementary Materials: The following are available online at https: / www.mdpi.com/article / 10.3390/biology10070637/s1, Table S1: Relative abundance of fecal bacterial microbiota for two populations of Mexican wolves (Canis lupus baileyi) in Michilia $\left(\mathrm{M}, 23^{\circ} \mathrm{N}\right)$ and Ocotal $\left(\mathrm{O}, 19^{\circ} \mathrm{N}\right)$, Mexico. This table shows all fecal bacterial taxa (from phylum to species) obtained for both Mexican wolves (Canis lupus baileyi) populations (Michilia and Ocotal).

Author Contributions: Conceptualization, S.I.B.-G. and C.G.-D.1.P.; Data curation, S.I.B.-G., I.P.-T. and M.A.V.-S.; Formal analysis, S.I.B.-G., C.G.-D.1.P. and V.Á.-R.; Funding acquisition, C.G.-D.l.P.; Investigation, C.E.D.-V., Q.K.S.-R. and J.C.H.-S.; Methodology, F.V.-P., C.E.D.-V., L.M.V.-N. and J.C.H.-S.; Resources, F.V.-P. and L.M.V.-N.; Software, C.E.D.-V.; Supervision, C.G.-D.1.P.; Writingoriginal draft, S.I.B.-G. and C.G.-D.1.P.; and Writing-review and editing, C.A.M.-H. and C.G.-D.1.P. All authors have read and agreed to the published version of the manuscript.

Funding: This research was funded by Laboratorio de Medicina de la Conservación, Facultad de Ciencias Biológicas, Universidad Juárez del Estado de Durango (0019) and Laboratorio Nacional en Salud: Diagnóstico Molecular y Efecto Ambiental en Enfermedades Crónico-Degenerativas, Facultad de Estudios Superiores Iztacala, Universidad Nacional Autónoma de México.

Institutional Review Board Statement: The study was approved by the Institutional Review Board of the Facultad de Ciencias Biológicas UJED research committee on 15 May 2016 (project number: 0019).

Informed Consent Statement: Not applicable.

Data Availability Statement: Fecal bacterial sequences are available on NCBI Bioproject PRJNA721093; SRA (SRP315294).

Acknowledgments: We thank the staff of La Michilia station and Ocotal park for the facilities provided in the collection of samples.

Conflicts of Interest: The authors declare no conflict of interest.

Ethics Statement : All procedures and methods used in this study regarding the use and care of animals were carried out in accordance with accepted international animal use and care guidelines.

\section{References}

1. Hale, V.L.; Tan, C.L.; Knight, R.; Amato, K.R. Effect of preservation method on spider monkey (Ateles geoffroyi) fecal microbiota over 8 weeks. J. Microbiol. Methods 2015, 113, 16-26. [CrossRef] [PubMed]

2. Borbón-García, A.; Reyes, A.; Vives-Flórez, M.; Caballero, S. Captivity shapes the gut microbiota of andean bears: Insights into health surveillance. Front. Microbiol. 2017, 8, 1316. [CrossRef]

3. Stumpf, R.M.; Gomez, A.; Amato, K.R.; Yeoman, C.J.; Polk, J.D.; Wilson, B.A.; Nelson, K.E.; White, B.A.; Leigh, S.R. Microbiomes, metagenomics, and primate conservation: New strategies, tools, and applications. Biol. Conserv. 2016, 199, 56-66. [CrossRef]

4. Cunningham, J.G.; Klein, B.G. Veterinary Physiology; Saunders Elsevier: Philadelphia, PA, USA, 2007.

5. Pagliari, D.; Piccirillo, C.A.; Larbi, A.; Cianci, R. The interactions between innate immunity and microbiota in gastrointestinal diseases. J. Immunol. Res. 2015, 898297. [CrossRef]

6. West, A.; Waite, D.; Deines, P.; Bourne, D.; Digby, A.; McKenzie, V.; Taylor, M. The microbiome in threatened species conservation. Biol. Conserv. 2019, 229, 85-98. [CrossRef]

7. Tag, A.C. Large Canid (Canidae) Care Manual; Association of Zoos and Aquariums: Silver Spring, MD, USA, 2012.

8. Bragg, M.; Freeman, E.W.; Lim, H.C.; Songsasen, N.; Muletz-Wolz, C.R. Gut Microbiomes Differ Among Dietary Types and Stool Consistency in the Captive Red Wolf (Canis rufus). Front. Microbiol. 2020, 11, 2777. [CrossRef]

9. Wu, X.; Zhang, H.; Chen, J.; Shang, S.; Yan, J.; Chen, Y.; Tang, X.; Zhang, H. Analysis and comparison of the wolf microbiome under different environmental factors using three different data of Next Generation Sequencing. Sci. Rep. 2017, 7, 11332. [CrossRef]

10. Lyu, T.; Liu, G.; Zhang, H.; Wang, L.; Zhou, S.; Dou, H.; Pang, B.; Sha, W.; Zhang, H. Changes in feeding habits promoted the differentiation of the composition and function of gut microbiotas between domestic dogs (Canis lupus familiaris) and gray wolves (Canis lupus). AMB Express 2018, 8, 1-12. [CrossRef] 
11. Carciofi, A.; Sakomura, N.; Kawauchi, I.; Vasconcellos, R. Digestibility and metabolizable energy of some carbohydrate sources for dogs. Anim. Feed Sci. Technol. 2010, 156, 121-125.

12. Hang, I.; Rinttila, T.; Zentek, J.; Kettunen, A.; Alaja, S.; Apajalahti, J.; Harmoinen, J.; de Vos, W.M.; Spillmann, T. Effect of high contents of dietary animal-derived protein or carbohydrates on canine faecal microbiota. BMC Vet. Res. 2012, 8, 1-9. [CrossRef]

13. Fitak, R.R.; Rinkevich, S.E.; Culver, M. Genome-wide analysis of SNPs is consistent with no domestic dog ancestry in the endangered Mexican wolf (Canis lupus baileyi). J. Hered. 2018, 109, 372-383. [CrossRef]

14. Servin, J. El periodo de apareamiento, nacimiento y crecimiento del lobo mexicano (Canis lupus baileyi). Acta Zoológica Mex. Nueva Ser. 1997, 71, 45-56.

15. Sinding, M.-H.S.; Gopalakrishan, S.; Vieira, F.G.; Samaniego Castruita, J.A.; Raundrup, K.; Heide Jørgensen, M.P.; Meldgaard, M.; Petersen, B.; Sicheritz-Ponten, T.; Mikkelsen, J.B. Population genomics of grey wolves and wolf-like canids in North America. PLoS Genet. 2018, 14, e1007745. [CrossRef]

16. Galindo, C. Recuperación del lobo Mexicano. In Patrimonio Natural de México. Cien Casos de Exito; Carabias, J., Sarukhán, J., de la Maza y, J., Galindo, C., Eds.; Comisión Nacional para el Conocimiento y Uso de la Biodiversidad: México, Mexico, D.F., 2010; pp. $80-81$.

17. SEGOB (Secretaría de Gobernación). NORMA Oficial Mexicana NOM-059-SEMARNAT-2010, Protección Ambiental-Especies Nativas de México de Flora y Fauna Silvestres-Categorías de Riesgo y Especificaciones para su Inclusión, Exclusión o Cambio-Lista de Especies en Riesgo; Diario Oficial de la Federación: Ciudad de México, Mexico, 2010.

18. USFWS (U.S. Fish and Wildlife Service). Mexican Wolf Recovery Plan, First Revision. Region 2, Albuquerque, New Mexico, USA. 2017. Available online: https:/ / www.fws.gov/southwest/es/mexicanwolf/pdf/2017MexicanWolfRecoveryPlanRevision1 Final.pdf (accessed on 15 February 2021).

19. SEMARNAT. Programa de Acción para la Conservación de la Especie, Lobo Gris Mexicano (Canis lupus baileyi). 2009. Available online: https://www.gob.mx/cms/uploads/attachment/file/251983/PACE_Lobo_Mexicano_2009.pdf (accessed on 16 February 2021).

20. FASS. Guide for the Care and Use of Agricultural Animals in Agricultural Research and Teaching, 3rd ed.; Animal Science Journal: Champaing, IL, USA, 2010; p. 177.

21. Gonzalez-Elizondo, S.; Gonzalez-Elizondo, M.; Cortes-Ortiz, A. Vegetación de la reserva de la biosfera La Michilia, Durango, México. Acta Botánica Mex. 1993, 22, 1-104. [CrossRef]

22. Aguilar-Campos, P. Diagnóstico Ambiental de la Zona Norte del Parque Estatal El Ocotal, en Timilpan, Estado de México. Bachelor's Thesis, Universidad Nacional Autónoma de México, México City, Mexico, 2009.

23. Klindworth, A.; Pruesse, E.; Schweer, T.; Peplies, J.; Quast, C.; Horn, M.; Glockner, F.O. Evaluation of general 16S ribosomal RNA gene PCR primers for classical and next-generation sequencing-based diversity studies. Nucleic Acids Res. 2013, 41, e1. [CrossRef]

24. Illumina. 16S Metagenomic Sequencing Library Preparation, Preparing 16S Ribosomal RNA Gene Amplicons for the Illumina MiSeq System. 2020. Available online: https://support.illumina.com/documents/documentation/chemistry_documentation/16 s/16s-metagenomic-library-prep-guide-15044223-b.pdf (accessed on 11 May 2021).

25. Illumina. Nextera XT DNA Library Prep Kit Reference Guide. Available online: https://support.illumina.com/content/ dam/illumina-support/documents/documentation/chemistry_documentation/samplepreps_nextera/nextera-xt/nextera-xtlibrary-prep-reference-guide-15031942-05.pdf (accessed on 11 May 2021).

26. Caporaso, J.G.; Kuczynski, J.; Stombaugh, J.; Bittinger, K.; Bushman, F.D.; Costello, E.K.; Fierer, N.; Pena, A.G.; Goodrich, J.K.; Gordon, J.I. QIIME allows analysis of high-throughput community sequencing data. Nat. Methods 2010, 7, 335. [CrossRef] [PubMed]

27. Zhang, J.; Kobert, K.; Flouri, T.; Stamatakis, A. PEAR: A fast and accurate Illumina Paired-End reAd mergeR. Bioinformatics 2014, 30, 614-620. [CrossRef] [PubMed]

28. Edgar, R.C. Search and clustering orders of magnitude faster than BLAST. Bioinformatics 2010, 26, 2460-2461. [CrossRef] [PubMed]

29. Yoon, S.-H.; Ha, S.-M.; Kwon, S.; Lim, J.; Kim, Y.; Seo, H.; Chun, J. Introducing EzBioCloud: A taxonomically united database of 16S rRNA gene sequences and whole-genome assemblies. Int. J. Syst. Evol. Microbiol. 2017, 67, 1613. [CrossRef] [PubMed]

30. Beals, E.W. Bray-Curtis ordination: An effective strategy for analysis of multivariate ecological data. Adv. Ecol. Res. 1984, 14, 1-55.

31. Vazquez-Baeza, Y.; Pirrung, M.; Gonzalez, A.; Knight, R. EMPeror: A tool for visualizing high-throughput microbial community data. GigaScience 2013, 2, 16. [CrossRef] [PubMed]

32. Clarke, K.R. Non-parametric multivariate analyses of changes in community structure. Aust. J. Ecol. 1993, 18, 117-143. [CrossRef]

33. Segata, N.; Izard, J.; Waldron, L.; Gevers, D.; Miropolsky, L.; Garrett, W.S.; Huttenhower, C. Metagenomic biomarker discovery and explanation. Genome Biol. 2011, 12, R60. [CrossRef] [PubMed]

34. Schmidt, M.; Unterer, S.; Suchodolski, J.S.; Honneffer, J.B.; Guard, B.C.; Lidbury, J.A.; Steiner, J.M.; Fritz, J.; Kölle, P. The fecal microbiome and metabolome differs between dogs fed Bones and Raw Food (BARF) diets and dogs fed commercial diets. PLoS ONE 2018, 13, e0201279. [CrossRef]

35. Isaiah, A.; Parambeth, J.C.; Steiner, J.M.; Lidbury, J.A.; Suchodolski, J.S. The fecal microbiome of dogs with exocrine pancreatic insufficiency. Anaerobe 2017, 45, 50-58. [CrossRef]

36. Trinh, P.; Zaneveld, J.R.; Safranek, S.; Rabinowitz, P.M. One health relationships between human, animal, and environmental microbiomes: A mini-review. Front. Public Health 2018, 6, 235. [CrossRef] 
37. Garcia-Mazcorro, J.F.; Dowd, S.E.; Poulsen, J.; Steiner, J.M.; Suchodolski, J.S. Abundance and short-term temporal variability of fecal microbiota in healthy dogs. Microbiol. Open 2012, 1, 340-347. [CrossRef]

38. Hand, D.; Wallis, C.; Colyer, A.; Penn, C.W. Pyrosequencing the canine faecal microbiota: Breadth and depth of biodiversity. PLoS ONE 2013, 8, e53115. [CrossRef] [PubMed]

39. Honneffer, J.B.; Steiner, J.M.; Lidbury, J.A.; Suchodolski, J.S. Variation of the microbiota and metabolome along the canine gastrointestinal tract. Metabolomics 2017, 13, 26. [CrossRef]

40. Bermingham, E.N.; Maclean, P.; Thomas, D.G.; Cave, N.J.; Young, W. Key bacterial families (Clostridiaceae, Erysipelotrichaceae and Bacteroidaceae) are related to the digestion of protein and energy in dogs. PeerJ 2017, 5, e3019. [CrossRef] [PubMed]

41. Song, S.J.; Lauber, C.; Costello, E.K.; Lozupone, C.A.; Humphrey, G.; Berg-Lyons, D.; Caporaso, J.G.; Knights, D.; Clemente, J.C.; Nakielny, S.; et al. Cohabiting family members share microbiota with one another and with their dogs. eLife 2013, 2, e00458. [CrossRef]

42. Pilla, R.; Suchodolski, J.S. The role of the canine gut microbiome and metabolome in health and gastrointestinal disease. Front. Vet. Sci. 2020, 6, 498. [CrossRef]

43. Reed, J.E.; Ballard, W.B.; Gipson, P.S.; Kelly, B.T.; Krausman, P.R.; Wallace, M.C.; Wester, D.B. Diets of free-ranging Mexican gray wolves in Arizona and New Mexico. Wildl. Soc. Bull. 2006, 34, 1127-1133. [CrossRef]

44. Merkle, J.; Stahler, D.; Smith, D. Interference competition between gray wolves and coyotes in Yellowstone National Park. Can. J. Zool. 2009, 87, 56-63. [CrossRef]

45. Zhu, L.; Wu, Q.; Deng, C.; Zhang, M.; Zhang, C.; Chen, H.; Lu, G.; Wei, F. Adaptive evolution to a high purine and fat diet of carnivorans revealed by gut microbiomes and host genomes. Environ. Microbiol. 2018, 20, 1711-1722. [CrossRef]

46. USFWS (U.S. Fish and Wildlife Service). Mexican Gray Wolf Husbandry Manual: Guidelines for Captive Management. 2009. Available online: https:/ / www.fws.gov/southwest/es/mexicanwolf/pdf/Mexican_Wolf_Husbandry_Manual_2009.pdf (accessed on 15 February 2021).

47. Henson, L.H.; Songsasen, N.; Waddell, W.; Wolf, K.N.; Emmons, L.; Gonzalez, S.; Freeman, E.; Maldonado, J. Characterization of genetic variation and basis of inflammatory bowel disease in the Toll-like receptor 5 gene of the red wolf and the maned wolf. Endanger. Species Res. 2017, 32, 135-144. [CrossRef]

48. Alessandri, G.; Milani, C.; Mancabelli, L.; Mangifesta, M.; Lugli, G.A.; Viappiani, A.; Duranti, S.; Turroni, F.; Ossiprandi, M.C.; van Sinderen, D. The impact of human-facilitated selection on the gut microbiota of domesticated mammals. FEMS Microbiol. Ecol. 2019, 95, fiz121. [CrossRef] [PubMed]

49. Moxham, G. Waltham feces scoring system-A tool for veterinarians and pet owners: How does your pet rate. Walth. Focus 2001, $11,24-25$.

50. Herstad, K.M.; Gajardo, K.; Bakke, A.M.; Moe, L.; Ludvigsen, J.; Rudi, K.; Rud, I.; Sekelja, M.; Skancke, E. A diet change from dry food to beef induces reversible changes on the faecal microbiota in healthy, adult client-owned dogs. BMC Vet. Res. 2017, 13, 1-13. [CrossRef]

51. Kim, J.; An, J.U.; Kim, W.; Lee, S.; Cho, S. Differences in the gut microbiota of dogs (Canis lupus familiaris) fed a natural diet or a commercial feed revealed by the Illumina MiSeq platform. Gut Pathog. 2017, 9, 68. [CrossRef]

52. Xenoulis, P.G.; Palculict, B.; Allenspach, K.; Steiner, J.M.; Van House, A.M.; Suchodolski, J.S. Molecular-phylogenetic characterization of microbial communities imbalances in the small intestine of dogs with inflammatory bowel disease. FEMS Microbiol. Ecol. 2008, 66, 579-589. [CrossRef] [PubMed]

53. Minamoto, Y.; Otoni, C.C.; Steelman, S.M.; Büyükleblebici, O.; Steiner, J.M.; Jergens, A.E.; Suchodolski, J.S. Alteration of the fecal microbiota and serum metabolite profiles in dogs with idiopathic inflammatory bowel disease. Gut Microbes 2015, 6, 33-47. [CrossRef] [PubMed] 